\title{
Healthcare, health and inequality in health in the Nordic countries
}

\author{
TERKEL CHRISTIANSEN ${ }^{1, *}$ \\ JØRGEN T. LAURIDSEN ${ }^{1}$ \\ MATHIAS KIFMANN ${ }^{2}$ \\ CARL HAMPUS LYTTKENS ${ }^{3}$ \\ THORHILDUR ÓLAFSDÓTTIR ${ }^{4}$ \\ HANNU VALTONEN ${ }^{5}$
}

\footnotetext{
${ }^{1}$ Department of Business and Economics, University of Southern Denmark, Denmark

${ }^{2}$ Hamburg Center for Health Economics, Universität Hamburg, Germany

${ }^{3}$ Department of Economics, University of Lund, Sweden

${ }^{4}$ Faculty of Business Administration, University of Iceland, Iceland

${ }^{5}$ Department of Social and Health Management, University of Eastern Finland, Finland
}

\begin{abstract}
All five Nordic countries emphasize equal and easy access to healthcare, assuming that increased access to healthcare leads to increased health. It is the purpose of the present study to explore to which extent the populations of these countries have reached good health and a high degree of socio-economic equality in health. Each of the five countries has established extensive public health programmes, although with somewhat different measures to increase health of the populations. We compare these countries to the UK and Germany by using data from the European Social Survey for 2002 and 2012 in addition to OECD statistics for the same years. Health is measured by self-assessed health in five categories, which is transformed to a cardinal scale using Swedish time trade-off (TTO) weights. As socio-economic measures we use household income and length of education. Socio-economic inequality in health is elicited in two ways. First, we show social gradients by comparing the percentage of respondents in the lower income group reporting good or very good health to the corresponding rates in the upper income group. Second, we show concentration indices of socio-economic related inequality in health. Everything else kept equal, good health and the size of the concentration index are negatively associated by definition. In 2012, mean health, based on Swedish weights applied to all countries, is above 0.93 in all the Nordic countries and the UK, but lower in Germany. Each of the Nordic countries have introduced centrally initiated comprehensive public health programmes to increase health and reduce socio-economic inequalities in health. In general, the Nordic countries have achieved good health for their populations as well as a high degree of socioeconomic equality in health. Improvements in life-style related determinants of health are possible, however.
\end{abstract}

JEL classification: I11, I14, I19

Key words: international comparison of health systems, health status, inequality in in health

* Correspondence to: Terkel Christiansen, Department of Business and Economics, University of Southern Denmark, Campusvej 55, DK 5230 Odense M. Denmark. E-mail: tch@sam.sdu.dk.

Published: Online June 2018. In print January 2019. dx.doi.org/10.5617/njhe.5955 


\section{Introduction}

There are five Nordic countries, Denmark, Finland, Iceland, Norway and Sweden, all of which adhere to the concept of a welfare state with healthcare as an important element and with equal and easy access to health care as an important goal (Lyttkens et al., 2016). These countries are characterized by predominantly tax financed healthcare and universal coverage. If socio-economic inequality in health care and health exists, it calls for political as well as research attention, either directly focusing on population segments with a low socio-economic status and low health, or indirectly through improved health in general, as these policies are interconnected. Among others, the OECD has reported inequality in health for member countries (OECD, 2015) as well as differences in self-reported health status by income (OECD, 2016, p. 72-73).

It is the aim of the present paper to investigate to which extent health systems in the Nordic countries have achieved good health for their populations as well as low socioeconomic inequality in health. The chosen indicators are compared to the corresponding indicators for two other countries, Germany and the UK. The reason for choosing these two countries is that they are neighbouring countries, are located in Western Europe and still have quite different health care systems. The German healthcare system is based on Chancellor Bismarck's model of a healthcare system which was implemented in the late $19^{\text {th }}$ century. The system consists of a statutory health insurance composed of self-regulated bodies with mandatory participation (member-based sickness funds) and private health insurance. Almost 90 percent of the population is covered by statutory health insurance. Members have free choice of sickness fund. Civil servants are insured by special government schemes and private health insurance. Furthermore, private health insurance provides coverage for most self-employed and employees who have opted out of the sickness fund system (Busse and Blümel, 2014).

The UK National Health Service (NHS) was created after the Second World War in accordance with Lord Beveridge's report (Beveridge, 1942). It is characterized by taxfinanced universal coverage for all citizens or residents. Entitlement depends on citizenship or residence in the country (Cylus et al., 2015).

The Nordic healthcare systems share the main characteristics of Lord Beveridge's National Health Service model, such as tax financing, public provision through public hospitals and general practitioners. GPs are self-employed and contract with the health service in Denmark and Norway while most GPs in Finland and Iceland are salaried and the payment varies in Sweden, but most GPs in Sweden are salaried (Olsen et al., 2016). In addition, there exist some private hospitals in the Nordic countries.

"Socioeconomic" usually refers to social and economic status. Due to difficulties in creating comparable groups defined by social status across countries, socioeconomic status is usually measured by income as a proxy variable in international comparisons. Length of education would be another indicator on a cardinal scale which can easily be documented.

Health is usually distributed inequitably across the population, and so are income and education. Income-related inequality in health measures the joint distribution of income and health when individuals are ranked by income. Similarly, education related inequality measures the joint distribution of health and education when individuals are ranked by length of education. We analyse both income and education related inequality based on individual level survey data.

Health and its distribution have numerous determinants which cannot be disentangled in the present paper, in particular due to data limitations at an individual level. Following this introduction, we describe public health policies and programmes on the basis of especially government reports and white papers from each country. Next, we use survey 
data from the European Social Survey (ESS) together with aggregate OECD data to describe socioeconomic inequality in health, non-medical determinants of health, health behaviour and resources allocated to healthcare. Finally, we discuss how these factors may have influenced the general health status as measured by self-assessed health, and its socioeconomic distribution.

\section{Public health policies and programmes in the Nordic countries, Germany and the UK}

The term "public health" is used in accordance with WHO's definition as "the art and science of preventing disease, prolonging life and promoting health through the organized efforts of society" (WHO, 2017).

The authors have made a review of the public health policies in the Nordic countries, Germany and the UK (Christiansen et al., 2018). The review showed that public health policies in the Nordic countries have much in common. All five countries have established public health institutes to monitor and analyse the health of the populations and have also set up public health education programmes. Furthermore, each country has adopted national public health programmes, including comprehensive vaccination programmes for children, and public health activities are initiated and run by the public sector on its own or in collaboration with NGOs.

The health of a population, however, does not only depend on public health programmes. Obviously, the structure and size of the curing health sector as well as many other sectors in society plays a role in influencing health, such as education or environment.

It is not possible a priori to hypothesize how these packages have worked, in particular how they have affected the populations' knowledge of risk factors, health behavior and health. The reasons are as follows: First, health of individuals may be the result of health behaviour and exposure over the life time. Second, the evidence of the effects of various programmes vary. Third, one has to consider how these pogrammes work together and finally the influence from other sectors in society plays a role as well.

White papers and government reports on public health from the various Nordic countries all show that public health has become an important policy issue during the last two decades or more. This development has undoubtedly been influenced by international trends, in particular trends that have been formulated by the WHO, as witnessed by direct references in some white papers. But in the Danish case the stagnation in life expectancy during the 1980s and early 1990s as analysed by the Government's Committee on Life Expectancy (Bjerregaard, 1994) has given impetus to improve public health.

National Health Service in the UK has similar characteristics to those of the Nordic systems with an emphasis on health promotion and equality of access. Health policy in the UK is comprehensive, and responsibility is centralized to a large extent. In contrast, the German system is characterized by a pluralistic and decentralized organization with less emphasis on centrally initiated public health programmes. Equality of access is something that is aimed for within a given insurance scheme, where it is specified as "solidarity" meaning access to all who have contributed with premiums and their dependents. No specific action plan at the central level has hitherto been in place to deal with inequality in health.

\section{Data}

For a quantitative comparison of health and inequality in health among the Nordic countries, data from the European Social Survey (ESS) were applied (European Social Survey, 2017). For Denmark, Finland, Norway and Sweden, data from Round 1 of 2002 were applied 
together with data from Round 2 of 2004 for Iceland, as data were not collected in Round 1 for Iceland. Results from these rounds are compared to results from Round 6 of 2012, in which all countries participated. Furthermore, we use OECD data to describe non-medical determinants of health and life expectancy. Health is measured by a self-assessed health variable with five categories which were converted to a cardinal scale using a Swedish scale developed by Burström et al. (2014). The authors used a time trade-off (TTO) model, based on EQ-5D health states, which were afterwards used to assign scales to the SAH categories (see the authors for details).

According to these authors, the following weights were applied to health status categories: Very good $=1$ (reference); good $=0.9685$; fair $=0.8586$; bad $=0.6811$; very bad $=0.5183$.

The post-sample design weights provided by the ESS variable PSPWGHT were applied to all calculations based on ESS data. These weights account for pre-sampling design representativeness issues and further adjust for post-sampling representativeness shortfalls (European Social Survey 2017). Table 1 shows some descriptive statistics for the sample. Descriptive aggregate data from the OECD Statistics are selected for the same years.

In the present study socio-economic related inequality in health is calculated by a concentration index showing either income-related inequality or education-related inequality in self-assessed health. The measure is relative to the mean of income or education in a given country which may vary from country to country. The index is described in a number of earlier studies, for example, van Doorslaer et al. (1997) and van Doorslaer and Koolman (2004), and is briefly summarized below. A concentration curve shows the cumulative share of a sample (ranked by socioeconomic status (SES) from lowest to highest) against the cumulative share of total health. If the curve coincides with the diagonal, everybody has the same health. If it is below the diagonal, there is an inequality in health to the advantage of the higher socioeconomic groups, and vice versa in case the curve lies above the diagonal. The index is measured by twice the area between the diagonal and the concentration curve. The greater the distance between the curve and the diagonal, the greater the inequality. The index varies between -1 and +1 for the hypothetically extreme situations where total health is concentrated either at those with the poorest or the highest socioeconomic status.

A calculation formula for the concentration index $\mathrm{C}$ which allows application of sample weights has been described by Kakwani et al., (1997):

$$
C=\frac{2}{n \mu} \sum_{i=1}^{n} w_{i} y_{i} R_{i}-1
$$

where $\mu=\frac{1}{n} \sum_{i=1}^{n} w_{i} y_{i}$ is the weighted average of health, $n$ is sample size, $y_{i}$ is health, $w_{i}$ is sample weights of individuals, which adds to $n$, and $R_{i}$ is the rank order, expressed as a fraction, defined by Kakwani et al. as

$$
R_{i}=\frac{1}{n} \sum_{j=1}^{i-1} w_{j}+\frac{w_{i}}{2}
$$

which is the cumulative fraction of the population up to the mid-point of each weight.

Post sample weights were used to weight results. Given that the calculation of the concentration index does not allow for weights being incorporated directly, the approach of van Doorslaer et al. (2004) was used; i.e., the weight for each observation was recalculated into $w_{i}=\operatorname{round}\left(w_{i} / \min _{j=1}^{n}\left(w_{j}\right)\right)$, and the observation was duplicated the number of times given by this number. 


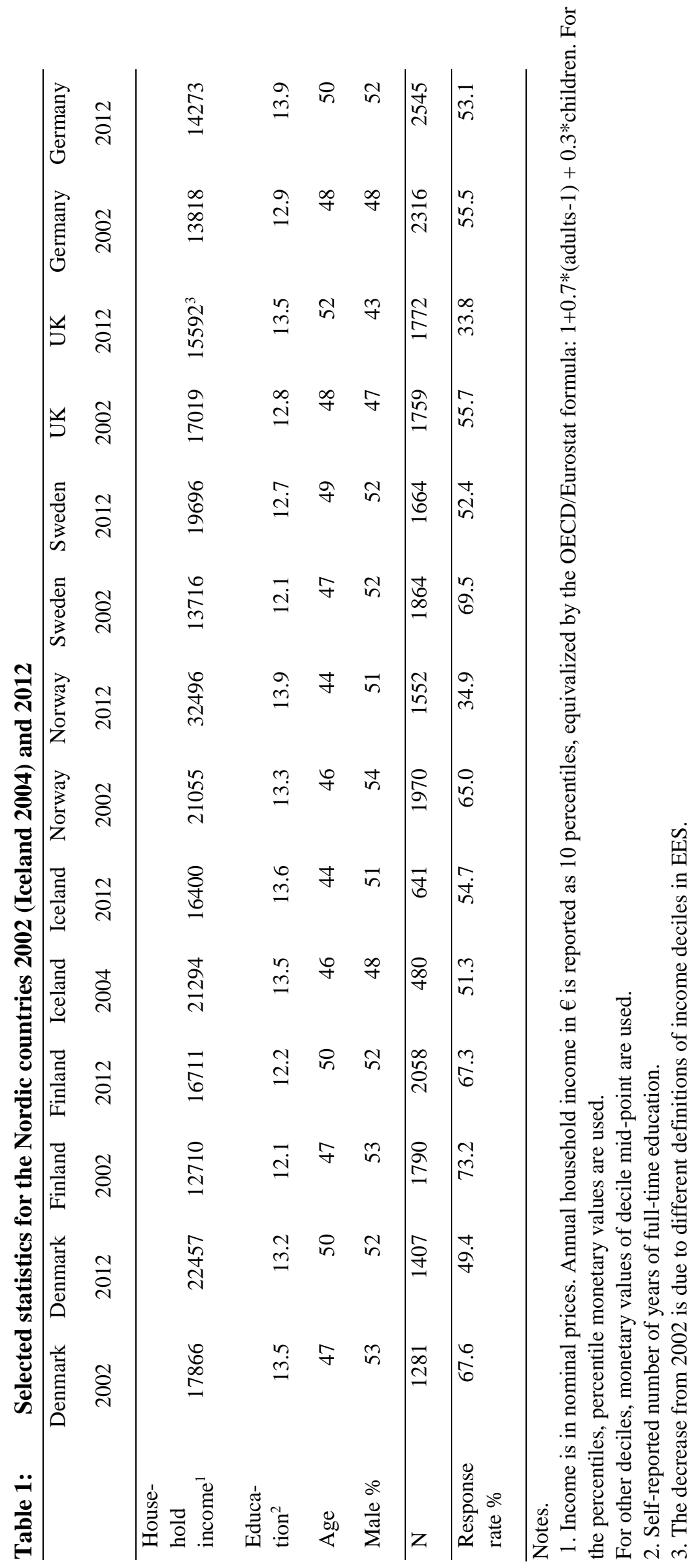




\section{Results}

\subsection{Health}

Mean health, based on self-assessed health reported in five categories and weighted by TTO weights, is shown in Figure 1. The level is above 0.93 in all Nordic countries and the UK in 2012, while being lower in Germany. The highest level was reached in Iceland in 2004 and Sweden in 2012. Only minor changes took place since 2002 in each country. Mean health and confidence intervals are shown in Table 2 .

Table 2: Socio-economic inequalities in health and mean health. Nordic countries, UK and Germany 2002 (Iceland 2004) and 2012

\begin{tabular}{|c|c|c|c|c|c|c|c|c|}
\hline Variable & $\begin{array}{l}\text { Denmark } \\
2002 \\
\end{array}$ & $\begin{array}{l}\text { Denmark } \\
2012 \\
\end{array}$ & $\begin{array}{l}\text { Finland } \\
2002 \\
\end{array}$ & $\begin{array}{l}\text { Finland } \\
2012 \\
\end{array}$ & $\begin{array}{l}\text { Iceland } \\
2004\end{array}$ & $\begin{array}{l}\text { Iceland } \\
2012 \\
\end{array}$ & $\begin{array}{l}\text { Norway } \\
2002 \\
\end{array}$ & $\begin{array}{l}\text { Norway } \\
2012 \\
\end{array}$ \\
\hline $\begin{array}{l}\text { Mean of } \\
\text { Health } \\
\text { (TTO) }\end{array}$ & $\begin{array}{l}0.947 \\
(0.945 \\
0.950)\end{array}$ & $\begin{array}{l}0.940 \\
(0.938 \\
0.942)\end{array}$ & $\begin{array}{l}0.932 \\
(0.929 \\
0.935)\end{array}$ & $\begin{array}{l}0.936 \\
(0.933 \\
0.938)\end{array}$ & $\begin{array}{l}0.953 \\
(0.949 \\
0.957)\end{array}$ & $\begin{array}{l}0.947 \\
(0.943, \\
0.951)\end{array}$ & $\begin{array}{l}0.939 \\
(0.937 \\
0.941)\end{array}$ & $\begin{array}{l}0.941 \\
(0.938 \\
0.944)\end{array}$ \\
\hline $\begin{array}{l}\text { SAH = } \\
\text { poor/very } \\
\text { poor }\end{array}$ & $\begin{array}{l}0.05 \\
(0.04 \\
0.06)\end{array}$ & $\begin{array}{l}0.05 \\
(0.04, \\
0.06)\end{array}$ & $\begin{array}{l}0.04 \\
(0.03 \\
0.05)\end{array}$ & $\begin{array}{c}0.03 \\
(0.03 \\
0.04)\end{array}$ & $\begin{array}{l}0.04 \\
(0.03 \\
0.05)\end{array}$ & $\begin{array}{c}0.04 \\
(0.03 \\
0.05)\end{array}$ & $\begin{array}{l}0.06 \\
(0.06, \\
0.07)\end{array}$ & $\begin{array}{l}0.06 \\
(0.05 \\
0.07)\end{array}$ \\
\hline $\begin{array}{l}\mathrm{SAH}= \\
\text { neutral }\end{array}$ & $\begin{array}{c}0.17 \\
(0.16 \\
0.18)\end{array}$ & $\begin{array}{l}0.21 \\
(0.20, \\
0.23)\end{array}$ & $\begin{array}{l}0.28 \\
(0.26 \\
0.30)\end{array}$ & $\begin{array}{l}0.26 \\
(0.24 \\
0.27)\end{array}$ & $\begin{array}{l}0.15 \\
(0.13, \\
0.17)\end{array}$ & $\begin{array}{l}0.18 \\
(0.17 \\
0.20)\end{array}$ & $\begin{array}{l}0.19 \\
(0.18, \\
0.20)\end{array}$ & $\begin{array}{l}0.17 \\
(0.15 \\
0.18)\end{array}$ \\
\hline $\begin{array}{l}\mathrm{SAH}= \\
\text { good/very } \\
\text { good }\end{array}$ & $\begin{array}{c}0.78 \\
(0.76 \\
0.79)\end{array}$ & $\begin{array}{l}0.74 \\
(0.72, \\
0.75)\end{array}$ & $\begin{array}{l}0.68 \\
(0.66 \\
0.70)\end{array}$ & $\begin{array}{c}0.71 \\
(0.69 \\
0.73)\end{array}$ & $\begin{array}{c}0.81 \\
(0.79 \\
0.83)\end{array}$ & $\begin{array}{c}0.78 \\
(0.75 \\
0.81)\end{array}$ & $\begin{array}{l}0.75 \\
(0.74, \\
0.76)\end{array}$ & $\begin{array}{l}0.77 \\
(0.76 \\
0.79)\end{array}$ \\
\hline $\begin{array}{l}\text { SAH = } \\
\text { good/very } \\
\text { good, } \\
\text { lower } \\
\text { income } \\
\text { grp., pct. }\end{array}$ & 0.696 & 0.638 & 0.57 & 0.624 & 0.615 & 0.735 & 0.609 & 0.697 \\
\hline $\mathrm{N}$ & 1281 & 1407 & 1790 & 2958 & 480 & 641 & 1970 & 1552 \\
\hline
\end{tabular}

ESS results are weighted with EES post-sample weights. $95 \%$ confidence interval in brackets, Source: European Social Survey 2002 and 2012. (European Social Survey 2017). 
Table 2: Socio-economic inequalities in health and mean health. Nordic countries, UK and Germany 2002 (Iceland 2004) and 2012 (continued)

\begin{tabular}{lcccccc}
\hline \multirow{2}{*}{ Variable } & Sweden & Sweden & UK & UK & Germany & Germa \\
& 2002 & 2012 & 2002 & 2012 & 2002 & 2012 \\
\cline { 2 - 7 } & & & & & & \\
Mean of & & & & & & \\
Health & 0.938 & 0.947 & 0.938 & 0.938 & 0.903 & 0.908 \\
(TTO) & $(0.935$, & $(0.945$, & $(0.938$, & $(0.936$, & $(0.901$, & $(0.907$, \\
& $0.940)$ & $0.949)$ & $0.939)$ & $0.940)$ & $0.905)$ & $0.909)$ \\
& & & & & & \\
SAH $=$ & 0.06 & 0.04 & 0.06 & 0.07 & 0.11 & 0.10 \\
poor/very & 0.05, & $(0.03$, & $(0.06$, & $(0.06$, & $(0.10$, & $(0.09$, \\
poor & $0.06)$ & $0.05)$ & $0.06)$ & $0.07)$ & $0.12)$ & $0.10)$ \\
& & & & & & \\
SAH $=$ & 0.21 & 0.17 & 0.19 & 0.18 & 0.32 & 0.31 \\
neutral & $(0.19$, & $(0.16$, & $(0.18$, & $(0.17$, & $(0.31$, & $(0.31$, \\
& $0.22)$ & $0.18)$ & $0.19)$ & $0.19)$ & $0.33)$ & $0.32)$ \\
& & & & & & \\
SAH $=$ & 0.73 & 0.79 & 0.75 & 0.75 & 0.57 & 0.59 \\
good/very & $(0.72$, & $(0.78$, & $(0.75$, & $(0.74$, & $(0.56$, & $(0.58$, \\
good & $0.75)$ & $0.80)$ & $0.76)$ & $0.77)$ & $0.58)$ & $0.60)$
\end{tabular}

$\mathrm{SAH}=$ good/very

good,

lower

income

\begin{tabular}{lllllll} 
grp., pct. & 0.666 & 0.712 & 0.644 & 0.660 & 0.480 & 0.493 \\
\hline $\mathrm{N}$ & 1864 & 1664 & 1759 & 1772 & 2316 & 2545
\end{tabular}

ESS results are weighted with EES post-sample weights. 95\% confidence interval in brackets, Source: European Social Survey 2002 and 2012. (European Social Survey 2017).

The distribution of categories of self-assessed health 2012 according to ESS data is shown in Figure 2. The average of combined categories "good" and "very good" is above or about 0.70 in all Nordic countries as well as the UK, while in Germany the share is below 0.60 . The share with poor or very poor health is lowest in Finland, Iceland and Sweden, while Germany has a higher share, followed by the UK. Minor changes have taken place since 2002 according to Table 2 . The share with good or very good health in the lower income group has increased in all countries except in Denmark.

Female life expectancy (LE) is shown in Figure 3. It has increased about equally in all countries and has reached more than 84 years in Iceland, followed by Finland and Sweden. Denmark is at the lowest level with 82 years, while UK and Germany have reached a level of about 83 years. As can be seen from Table 3, the gender difference in LE has decreased since 2002, and male LE is between 2.7 and six years lower than female LE in the Nordic countries in 2012.

Overweight defined as $\mathrm{BMI} \geq 25$ has increased in all included countries during the decade. In 2011, it varied between 33 per cent of the population in Denmark and 38 per cent 
in Iceland, followed by Norway and Sweden. The level in Germany lies slightly below Iceland. Overweight by country is shown in Figure 4 and documented in Table 3.

Figure 1: Mean health on a 0-1 scale, based on self-assessed health with health categories weighted by TTO weights. The Nordic countries, UK and Germany, 2002 and 2012

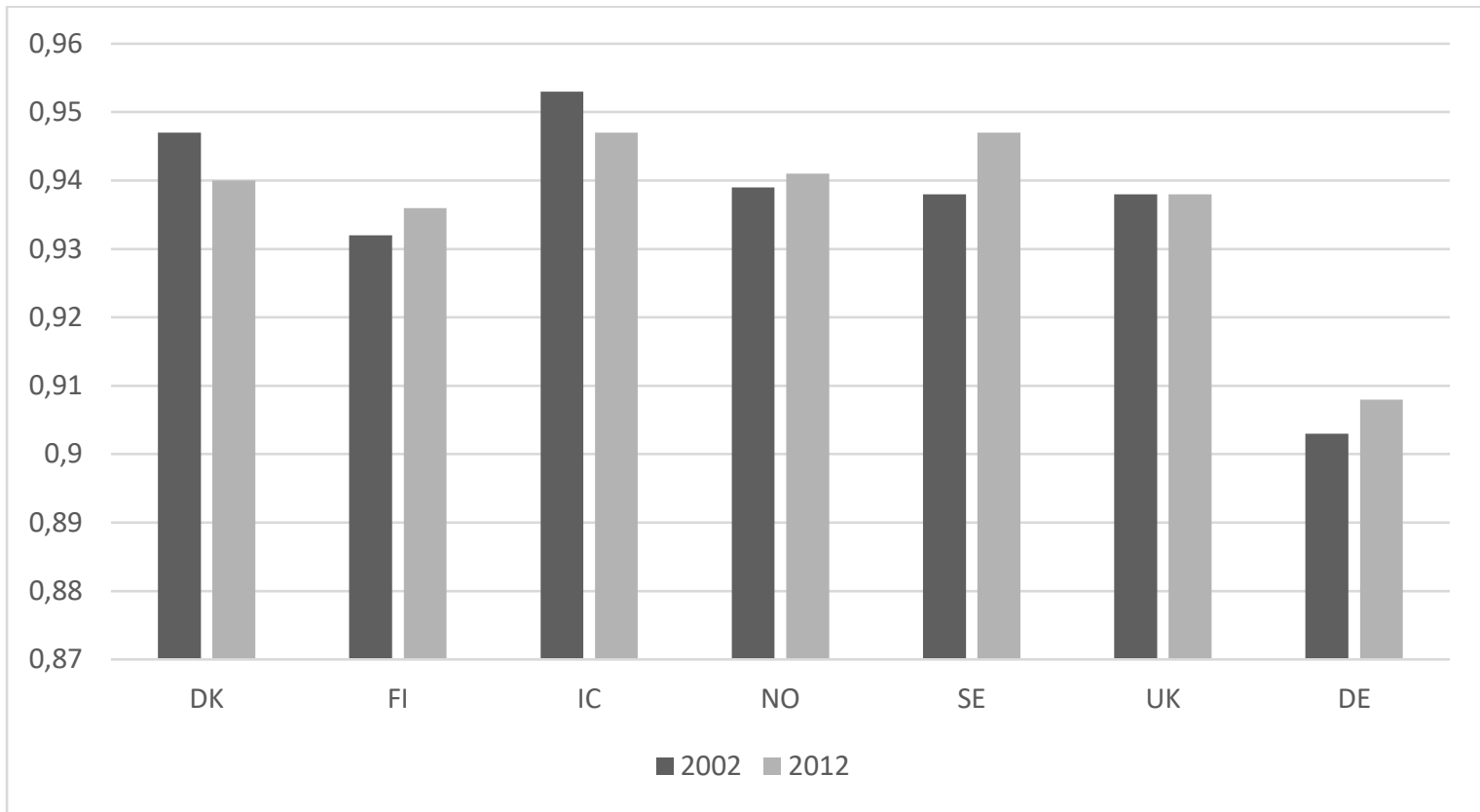

Source: European Social Survey 2002 and 2012. (European Social Survey, 2017).

Figure 2: Self-assessed health status by category in the Nordic countries, UK and Germany, 2012

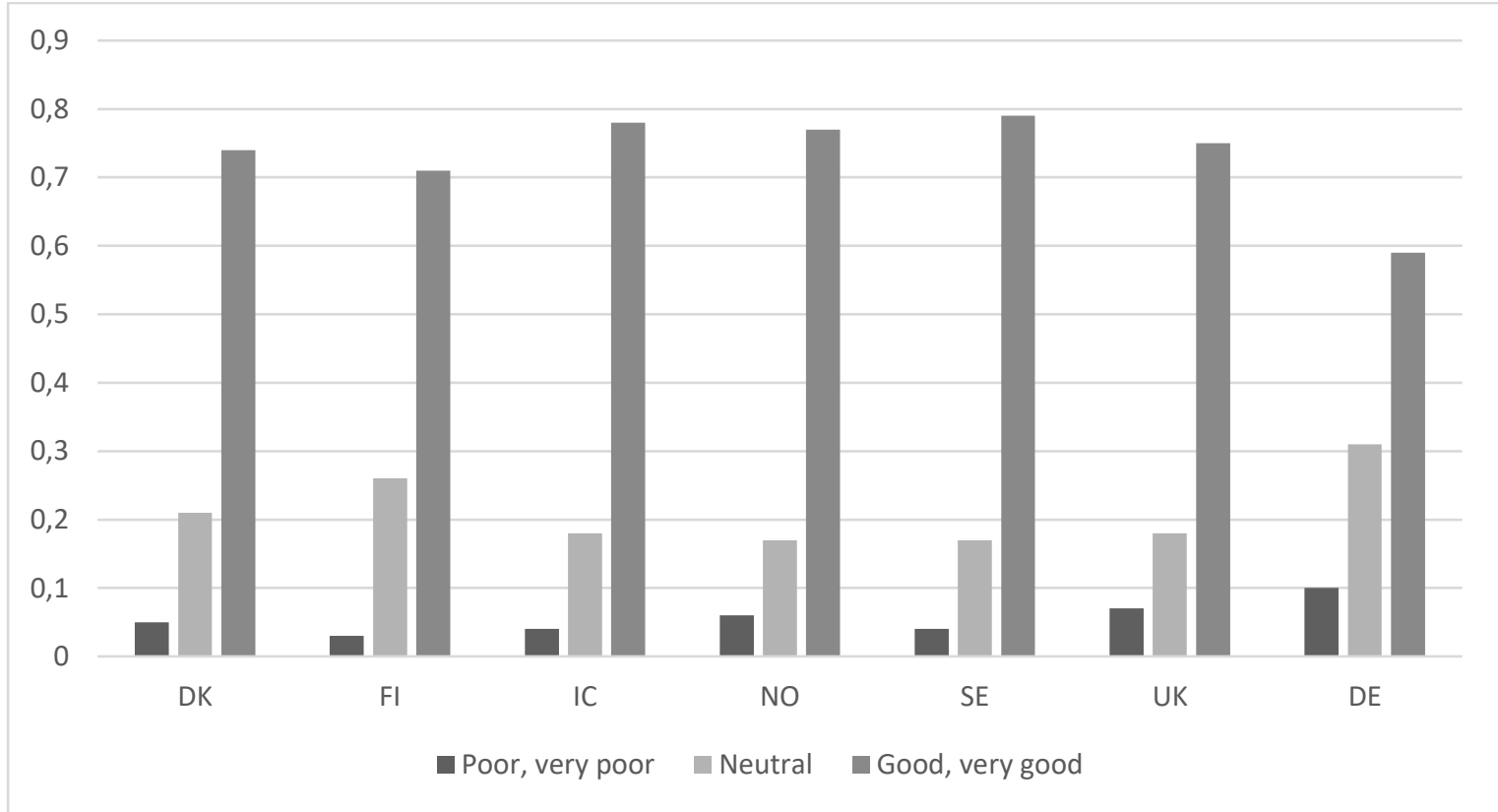

Source: European Social Survey 2012 (European Social Survey, 2017). 
Table 3: Life expectancy, overweight and concentration indices, Nordic countries, UK and Germany 2002 and 2012. Gini coefficients 2012

\begin{tabular}{|c|c|c|c|c|c|c|c|c|}
\hline & Denmark & Denmark & Finland & Finland & Iceland & Iceland & Norway & Norway \\
\hline & 2002 & 2012 & 2002 & 2012 & 2004 & 2012 & 2002 & 2012 \\
\hline LE, fem. ${ }^{1}$ & 79.4 & 82.1 & 81.6 & 83.7 & 82.5 & 84.3 & 81.6 & 83.5 \\
\hline $\begin{array}{l}\text { Difference } \\
\text { F-M }^{1}\end{array}$ & 4.6 & 4.0 & 6.7 & 6.0 & 3.9 & 2.7 & 5.2 & 4.0 \\
\hline $\begin{array}{l}\text { Overweight* } \\
\text { BMI } \geq 25\end{array}$ & 32.2 & 33.3 & 33.5 & 34.1 & 35.9 & 37.5 & 34.0 & 36.0 \\
\hline $\begin{array}{l}\text { Gini } \\
\text { coefficient }\end{array}$ & & $\begin{array}{l}0.231 \\
(0.227, \\
0.234)\end{array}$ & & $\begin{array}{l}0.237 \\
(0.232 \\
0.241)\end{array}$ & & $\begin{array}{l}0.172 \\
(0.167 \\
0.179)\end{array}$ & & $\begin{array}{l}0.223 \\
(0.218, \\
0.228)\end{array}$ \\
\hline $\begin{array}{l}\text { Concentra- } \\
\text { tion index, } \\
\mathrm{C} \text {, ranked by } \\
\text { income }\end{array}$ & $\begin{array}{l}0.008 \\
(0.006, \\
0.009)\end{array}$ & $\begin{array}{l}0.011 \\
(0.010 \\
0.012)\end{array}$ & $\begin{array}{l}0.010 \\
(0.009 \\
0.012)\end{array}$ & $\begin{array}{l}0.007 \\
(0.005 \\
0.009)\end{array}$ & $\begin{array}{l}0.009 \\
(0.007 \\
0.012)\end{array}$ & $\begin{array}{l}0.002 \\
(0.000 \\
0.005)\end{array}$ & $\begin{array}{l}0.010 \\
(0.009 \\
0.012)\end{array}$ & $\begin{array}{l}0.010 \\
(0.008, \\
0.012)\end{array}$ \\
\hline $\begin{array}{l}\text { Concentra- } \\
\text { tion index, } \\
\text { C, ranked by } \\
\text { education }\end{array}$ & $\begin{array}{l}0,008 \\
(0.006 \\
0.009)\end{array}$ & $\begin{array}{l}0,011 \\
(0.010 \\
0.012)\end{array}$ & $\begin{array}{l}0,01 \\
(0.009 \\
0.012)\end{array}$ & $\begin{array}{l}0,007 \\
(0.005 \\
0.009)\end{array}$ & $\begin{array}{l}0,009 \\
(0.007 \\
0.012)\end{array}$ & $\begin{array}{l}0,002 \\
(0.000 \\
0.005)\end{array}$ & $\begin{array}{l}0,01 \\
(0.009 \\
0.012)\end{array}$ & $\begin{array}{l}0,01 \\
(0.008, \\
0.012)\end{array}$ \\
\hline $\mathrm{N}$ & 1281 & 1407 & 1790 & 2058 & 480 & 641 & 1970 & 1552 \\
\hline
\end{tabular}

Notes: Income is in nominal prices. ESS results are weighted with ESS post-sample weights. 95\% confidence interval in parenthesis.

${ }^{1}$ Based on OECD Statistics (OECD 2017b); * refers to the years 2002 and 2011.

Source: European Social Survey 2002 and 2012. (European Social Survey, 2017). 
Table 3: Life expectancy, overweight and concentration indices, Nordic countries, UK and Germany 2002 and 2012. Gini coefficients 2012 (continued)

\begin{tabular}{|c|c|c|c|c|c|c|}
\hline Variable & $\begin{array}{l}\text { Sweden } \\
2002\end{array}$ & $\begin{array}{l}\text { Sweden } \\
2012\end{array}$ & $\begin{array}{l}\text { UK } \\
2002\end{array}$ & $\begin{array}{l}\text { UK } \\
2012\end{array}$ & $\begin{array}{l}\text { Germany } \\
2002\end{array}$ & $\begin{array}{l}\text { Germany } \\
2012\end{array}$ \\
\hline LE, females ${ }^{1}$ & 82.1 & 83.6 & 80.6 & 82.8 & 81.3 & 83.3 \\
\hline $\begin{array}{l}\text { Difference } \\
\text { F-M }^{1}\end{array}$ & 4.4 & 3.7 & 4.6 & 3.7 & 5.6 & 4.7 \\
\hline $\begin{array}{l}\text { Overweight* } \\
\text { BMI } \geq 25\end{array}$ & 34.4 & 35.3 & & & 36.3 & 36.7 \\
\hline $\begin{array}{l}\text { Gini } \\
\text { coefficient }\end{array}$ & & $\begin{array}{l}0.219 \\
(0.215 \\
0.222)\end{array}$ & & $\begin{array}{l}0.304 \\
(0.300 \\
0.308)\end{array}$ & & $\begin{array}{l}0.250 \\
(0.248 \\
0.251)\end{array}$ \\
\hline $\begin{array}{l}\text { Concentration } \\
\text { index, C, } \\
\text { ranked by } \\
\text { income }\end{array}$ & $\begin{array}{l}0.007 \\
(0.005 \\
0.008)\end{array}$ & $\begin{array}{l}0.007 \\
(0.005 \\
0.009)\end{array}$ & $\begin{array}{l}0.012 \\
(0.011 \\
0.012)\end{array}$ & $\begin{array}{l}0.012 \\
(0.011 \\
0.013)\end{array}$ & $\begin{array}{l}0.009 \\
(0.008 \\
0.011)\end{array}$ & $\begin{array}{l}0.011 \\
(0.011 \\
0.012)\end{array}$ \\
\hline $\begin{array}{l}\text { Concentration } \\
\text { index, C, } \\
\text { ranked by } \\
\text { income }\end{array}$ & $\begin{array}{l}0.007 \\
(0.005 \\
0.008)\end{array}$ & $\begin{array}{l}0.007 \\
(0.005 \\
0.009)\end{array}$ & $\begin{array}{l}0.012 \\
(0.011 \\
0.012)\end{array}$ & $\begin{array}{l}0.012 \\
(0.011 \\
0.013)\end{array}$ & $\begin{array}{l}0.009 \\
(0.008 \\
0.011)\end{array}$ & $\begin{array}{l}0.011 \\
(0.011 \\
0.012)\end{array}$ \\
\hline $\mathrm{N}$ & 1864 & 1664 & 1759 & 1772 & 2316 & 2545 \\
\hline
\end{tabular}

Notes: Income is in nominal prices. ESS results are weighted with ESS post-sample weights. 95\% confidence interval in brackets.

${ }^{1}$ Based on OECD Statistics (OECD 2017b); * refers to the years 2002 and 2011.

Source: European Social Survey 2002 and 2012. (European Social Survey, 2017). 
Figure 3: Life expectancy, females at birth, Nordic countries, UK and Germany, 2002 and 2012

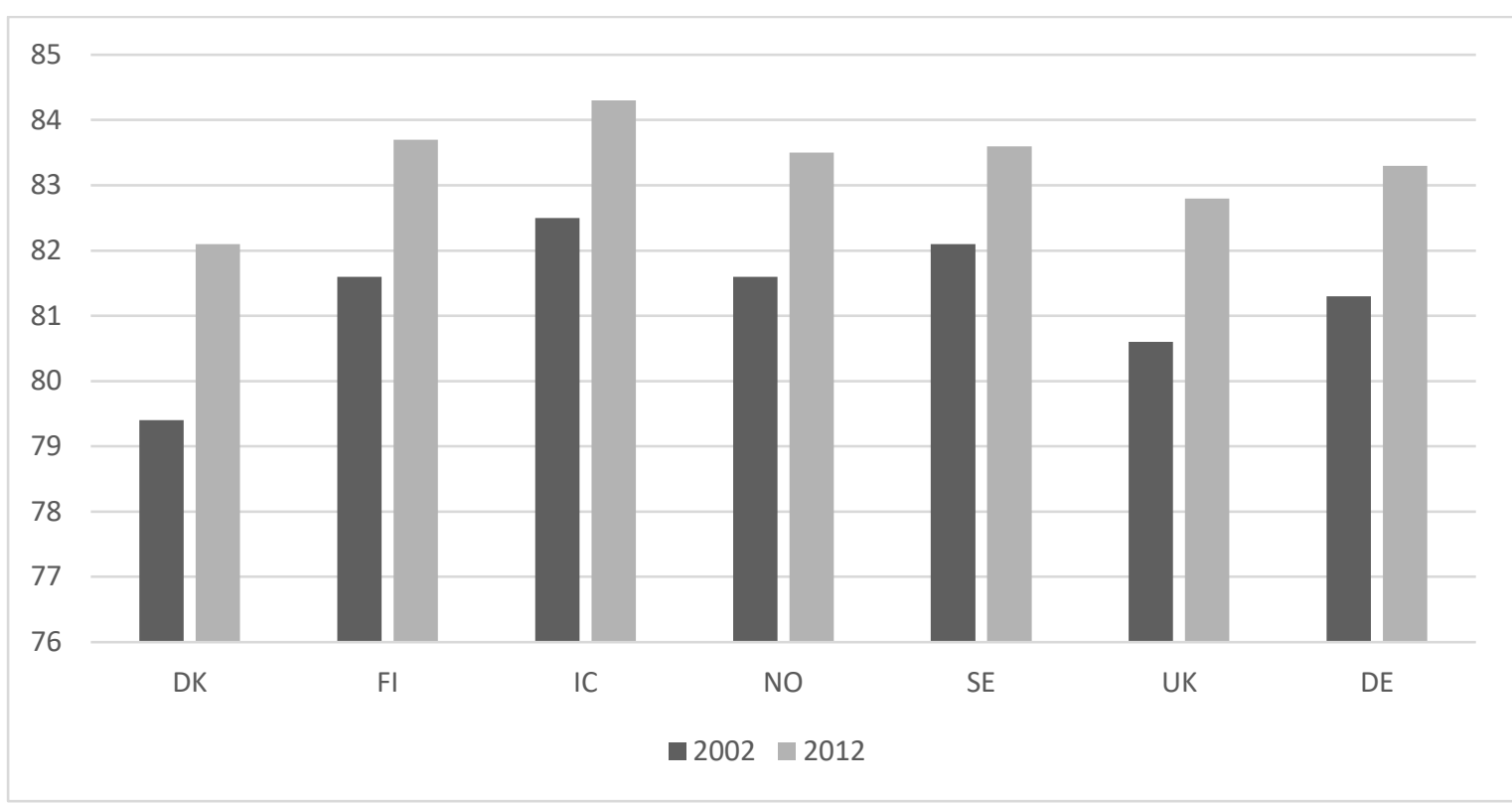

Source: OECD Statistics (OECD, 2017).

Figure 4: Overweight as share of the population in the Nordic countries and Germany, 2002 and 2011

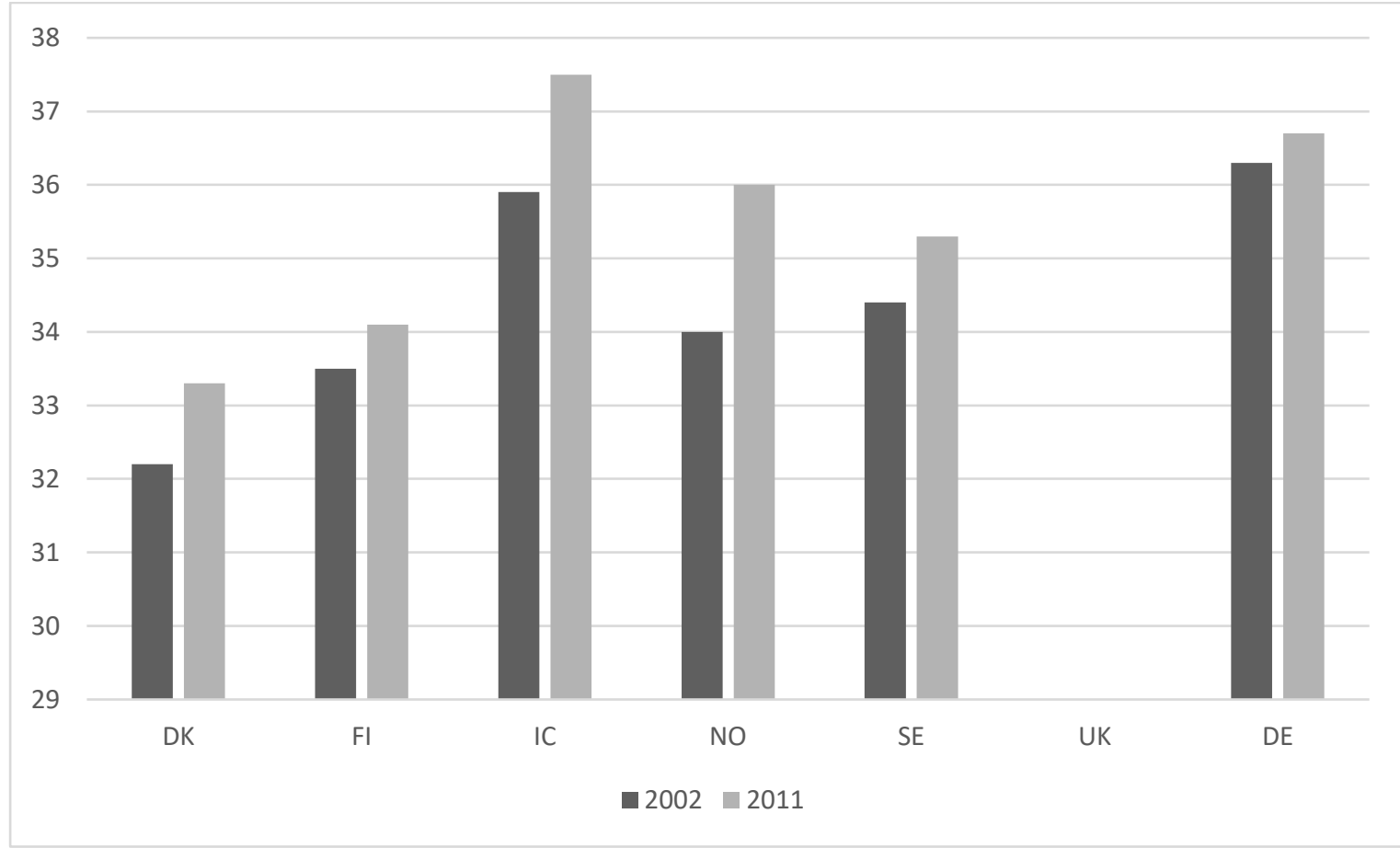

Source: OECD Statistics, (OECD, 2017a). 


\subsection{Income distribution}

Inequality in income as measured by the Gini coefficient is shown in Figure 5. The coefficient in Denmark, Finland, Norway and Sweden are at about the same level while Iceland lies below and the UK and Germany lie above. Thus, income inequality in the Nordic countries is below the level of the benchmarking countries. Data are documented in Table 3. While a skewed distribution of income does not in itself lead to inequality in income-related health, such a relationship would arise if income and health are associated. Earlier studies have indicated that although social welfare state like the Scandinavian countries have relatively low inequality in income, there is no corresponding low incomerelated inequality in health as shown by Dahl et al. (2014) and Lahelma and Lundberg (2009).

Figure 5: Income inequality as measured by the Gini coefficient. Based on equivalized household income in the Nordic countries, UK and Germany, 2012

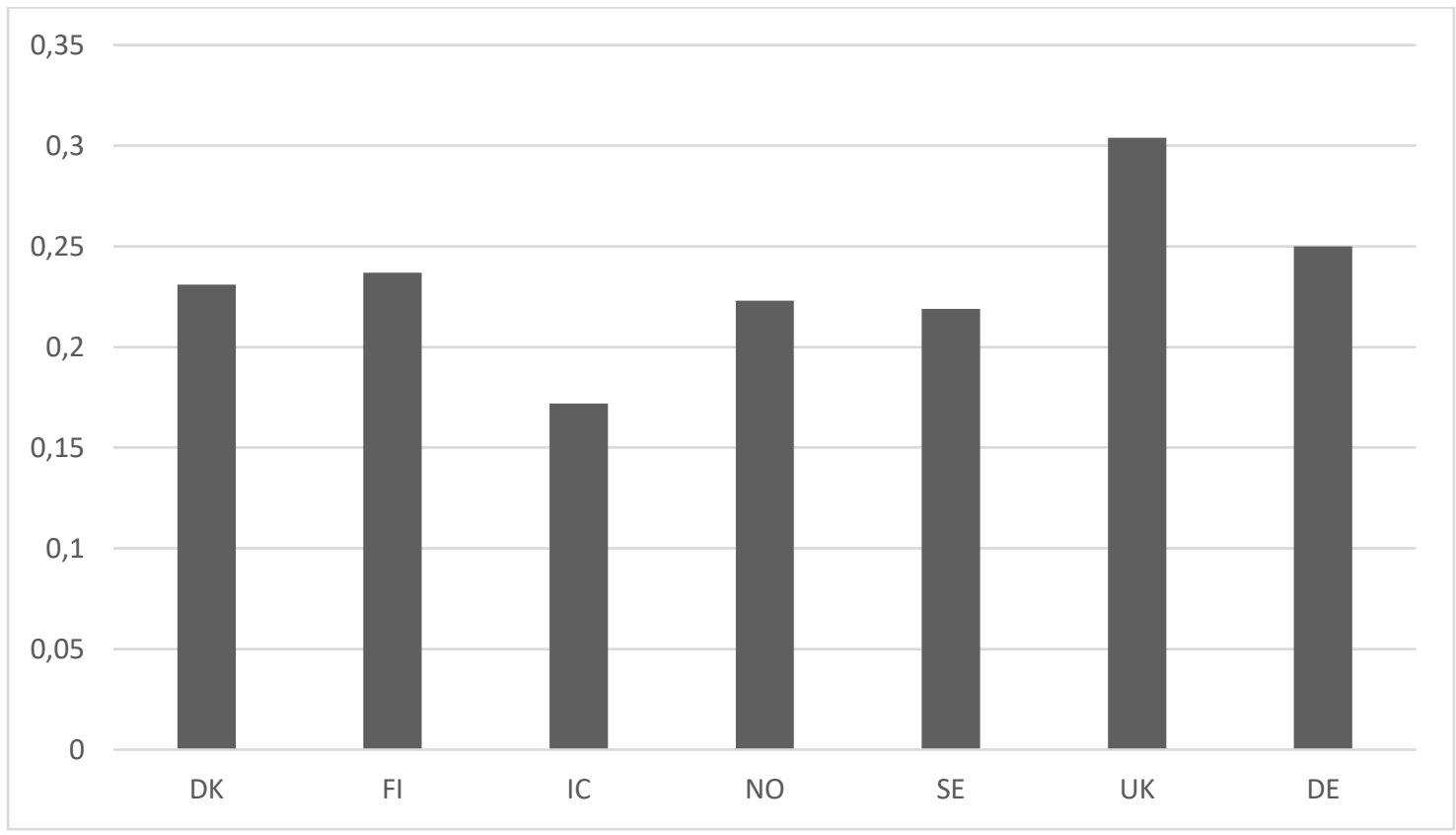

Source: European Social Survey 2012 (European Social Survey, 2017).

\subsection{Income- and education-related inequality in health}

Figure 6 shows the percentage of respondents reporting good or very good self-reported health by countries and income group (lower half versus upper half). Different patterns are seen. For Denmark, the percentage among the lower income group has reduced from 2002 to 2012, while the percentage has increased for the upper income group. For Germany, the percentage has increased for both groups, but the increase is larger for the upper than for the lower income group. Thus, inequality in health has increased for Denmark and Germany. For Finland, Iceland, Norway and Sweden, the percentages rose faster for the lower income groups than for the upper ones, thus indicating reductions in inequality. For UK, both income groups had approximately the same increase from 2002 to 2012, which indicates that inequality was unchanged over time. 
Figure 6: Good and very good self-assessed health in lower and upper half of income groups in the Nordic countries, UK and Germany, 2002 and 2012

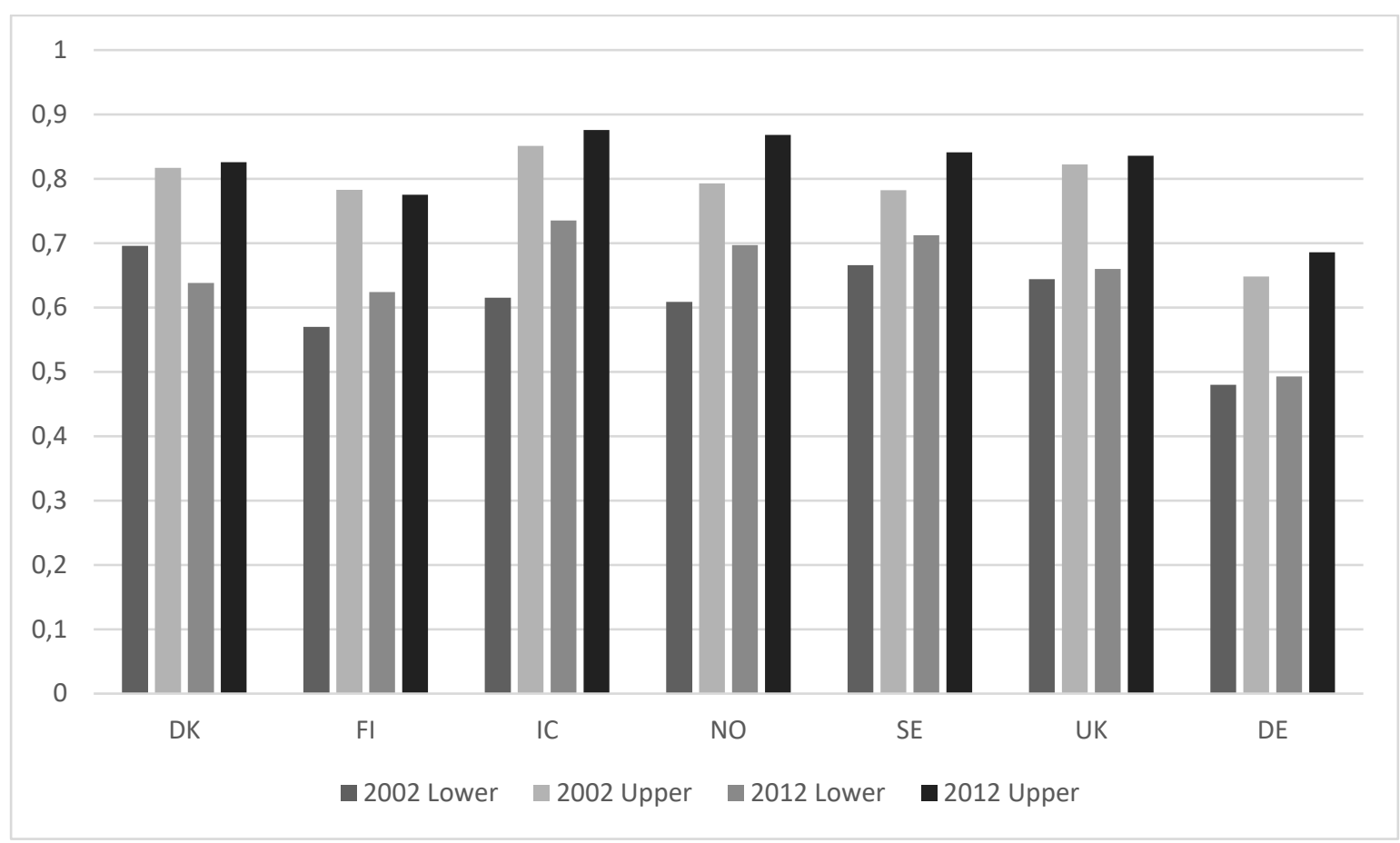

Source: European Social Survey 2012 (European Social Survey, 2017).

Figure 7: Income-related inequality in self-assessed health as measured by the concentration index (C), Nordic countries, UK and Germany, 2002 and 2012

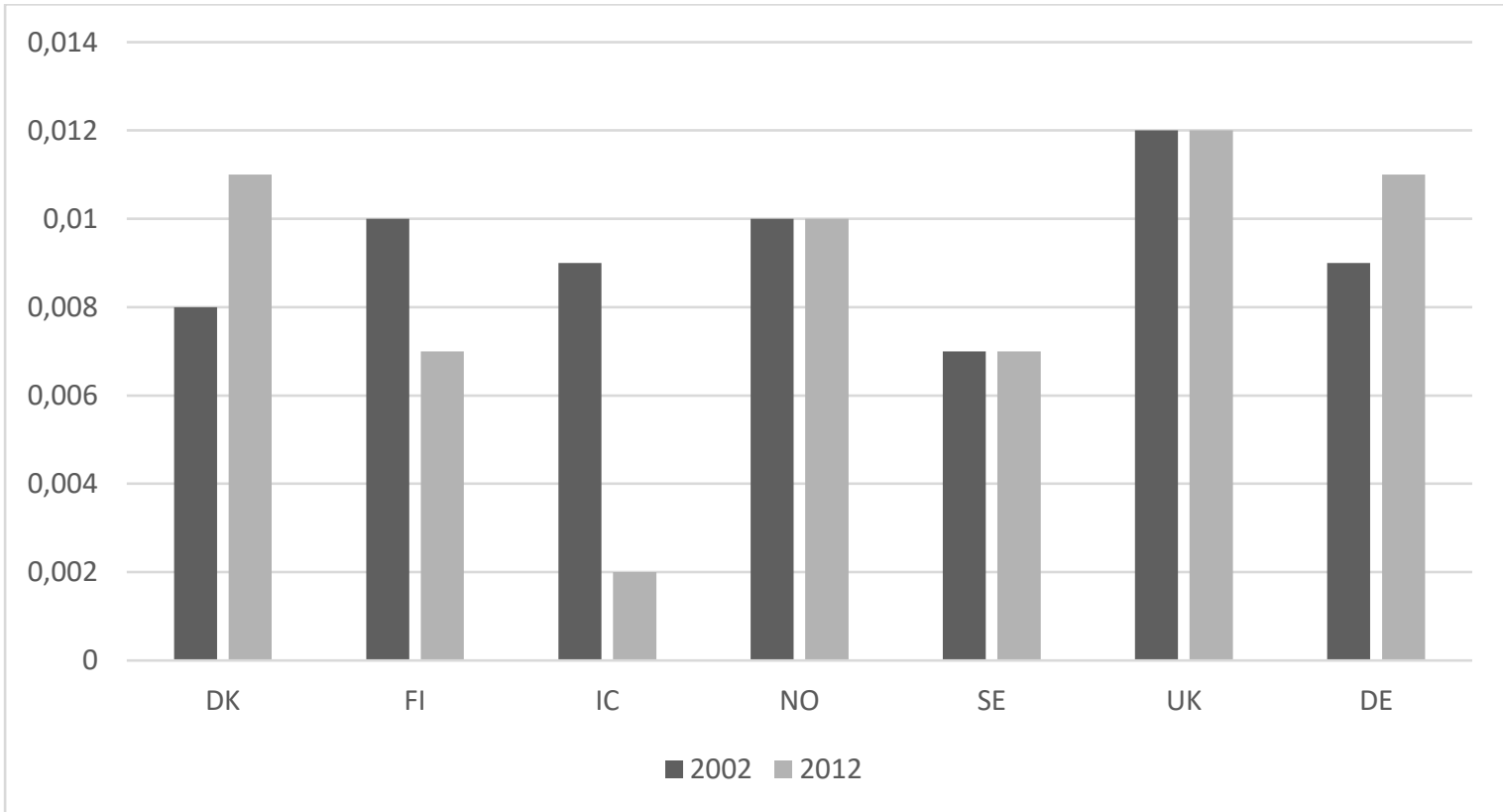

Source: European Social Survey 2012 (European Social Survey, 2017).

Figure 7 compares income-related inequality in health among the Nordic countries as measured by the concentration index. These results, together with confidence intervals, are documented in Table 3. By comparing these confidence intervals, it can furthermore be 
assessed whether differences in concentration indices are significant. When the indices for two years are compared, it has to be taken into consideration that the populations may have changed over time. Similarly, when we compare countries, the population composition may be different, and hence results should be interpreted with caution. While in 2012 the concentration index is relatively low in Iceland, Finland and Sweden and significantly lower than in the benchmark countries, it is higher in Denmark and Norway. Still, the indices for the UK and Germany are higher, although not significantly so than in Denmark and Norway. The indices have increased significantly for Denmark and Germany since 2002, while they have decreased significantly for Finland and Iceland. For Norway, Sweden, Germany and the UK, the concentration indices are unchanged.

The histogram in Figure 6 shows a social gradient when we compare lower and upper income groups for a given country, which is easily interpreted (for example, a difference between 0.7 and 0.8 on a self-assessed scale for Denmark in 2002). The concentration indices in Figure 7 are based on a distribution of self-assessed health over the whole range of income. In the case of Denmark in 2002, the figure provides an index of 0.008 and, when illustrated in a graph, the concentration curve almost coincides with the diagonal and shows no substantial income-related inequality in health. Due to the curve being close to the diagonal, it is not shown in a figure. Hence, the two approaches - the social gradient and the concentration curve - give different impression of income-related inequality in health, although the figures are based on the same data.

We calculated the concentration index for education-related inequality in health and found comparable results with a concentration curve very close to the diagonal in all countries showing no substantial education-related inequality in health.

\subsection{Non-medical determinants of ill-health}

As shown in Table 2, health inequality exists among income groups, although it is very small when weighted by preference weights. One interesting question would be how far the Nordic countries have come in reducing non-medical determinants of ill-health, in particular life-style related determinants of ill-health. Among data from OECD Statistics (OECD 2017a), we show the consumption of tobacco, alcohol, sugar and fat in Table 4.

The consumption of tobacco has decreased in all countries except for Finland since 2002. The level in the Nordic countries lies between the UK with the lowest level and Germany with the highest level. The level for Sweden in 2011 is not available due to the extensive use of snuff as a substitute for tobacco.

Alcohol consumption has decreased in Denmark, but from the highest level among the compared countries. For the other Nordic countries there were some increases. For UK and Germany the consumption decreased, but also from a relatively high level.

The consumption of sugar varies substantially among the countries. An extreme level is found for Denmark with more than $50 \mathrm{~kg}$ per person per year, while in Finland the consumption is $30 \mathrm{~kg}$. The other countries have a level in between, and it decreased in all countries except for the UK.

Fat consumption has increased in all countries during the decade studied. It varies between $132 \mathrm{~g} /$ person/day in Denmark and Sweden and $150 \mathrm{~g}$ in Norway. UK and Germany lie between these extremes.

The cobweb diagram in Figure 8 shows the distribution of each of the four nonmedical determinants of health by country. Each determinant is shown by an index relative to the highest value among countries. For example, tobacco consumption is shown relative to the consumption in Germany, where it is the highest. Germany appears to be relatively high on three of the determinants, followed by the UK and Denmark. 
Table 4: Consumption of tobacco, alcohol, sugar and fat, Nordic countries, UK and Germany, 2002 and 2011

\begin{tabular}{|c|c|c|c|c|c|c|c|c|c|}
\hline Substance & Units & Year & Denmark & Finland & Iceland & Norway & Sweden & UK & Germany \\
\hline \multirow[t]{2}{*}{ Tobacco } & g/capita/year & 2002 & 1522 & 1012 & 1724 & 1391 & 1713 & 1224 & 2396 \\
\hline & (15+ years) & 2011 & 1250 & 1221 & 1230 & 1073 & n.a. & 955.4 & 1664 \\
\hline \multirow[t]{2}{*}{ Alcohol } & 1/capita/year & 2002 & 13.1 & 9.2 & 6.6 & 5.9 & 6.9 & 11.1 & 12.3 \\
\hline & $(15+$ years $)$ & 2011 & 10.5 & 9.8 & 8.1 & 6.4 & 7.4 & 9.9 & 11.2 \\
\hline \multirow[t]{2}{*}{ Sugar } & $\mathrm{kg} / \mathrm{capita} /$ year & 2002 & 57.6 & 34.8 & 52.3 & 44.3 & 42.1 & 41.1 & 45.2 \\
\hline & & 2011 & 53.3 & 30.8 & 46.6 & 40.1 & 40.1 & 47.8 & 40.1 \\
\hline \multirow[t]{2}{*}{ Fat } & g/capita/day & 2002 & 130.4 & 127.5 & 137.9 & 145.7 & 125.1 & 135.4 & 139 \\
\hline & & 2011 & 132.3 & 136.7 & 146.2 & 150.3 & 132.1 & 138.1 & 145.8 \\
\hline
\end{tabular}

Source: OECD (2017a)

Figure 8: Relative distribution of non-medical determinants of health by country, 2011

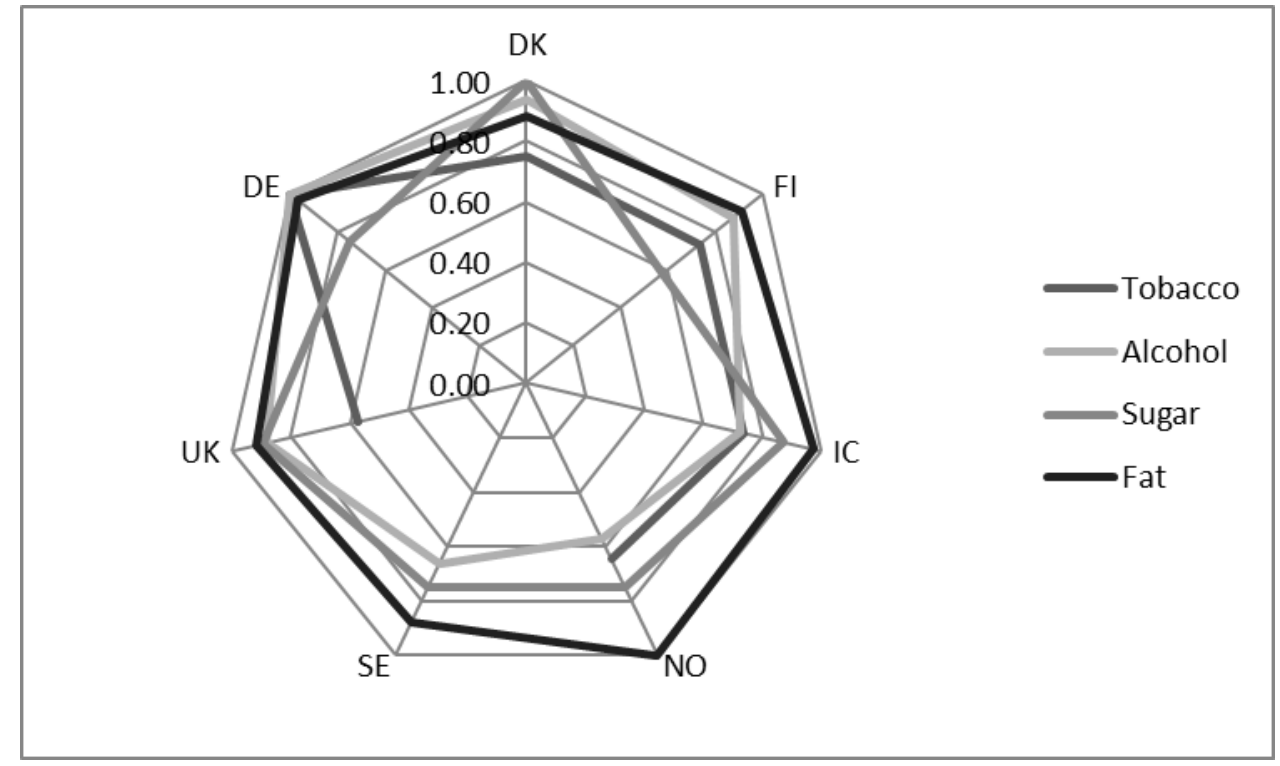

Source: Based on OECD Statistics (2017a).

\subsection{Resources allocated to health}

Human resources allocated to healthcare and expenditure on health are shown in Table 5, based on OECD (2017b). The share of the population employed in health care varies substantially from country to country. Among the Nordic countries it increased in Finland and Norway during the decade, while it decreased in the other Nordic countries. The lowest level in 2012 is seen in Iceland, the UK and Denmark, all with about 6 per cent. Norway has by far the highest share close to 11 pct. Definitions may vary between countries, however.

The share of GDP used for healthcare has increased in all countries except for Iceland. Sweden has the highest share close to 11 per cent, followed by Denmark. Norway 
has the lowest share, but of the highest GDP. Denmark, Finland and Iceland are at a level between the UK and Germany in 2012.

Current expenditure on health, measured in US dollars, is by far the highest in Norway with more than 5700 dollars, followed by Sweden and Denmark. Denmark is at the level of Germany while Iceland is at the level of the UK. Out-of-pocket expenditure on healthcare has increased in all countries with the highest levels being found in Norway and Sweden in 2012.

Table 5: Human resources in health care and expenditure on health in the Nordic countries, UK and Germany, 2002 and 2012

\begin{tabular}{llllllllll}
\hline & Units & Year & Denmark & Finland & Iceland & Norway & Sweden & UK & Germany \\
\hline Employed & Pct. of pop & 2002 & 9.29 & 6.06 & 7.65 & 9.64 & 8.87 & 3.75 & 4.56 \\
& & 2012 & 8.89 & 7.56 & 6.02 & 10.86 & 7.54 & 6.16 & 6.06 \\
Current & US doll/ & 2002 & 2750 & 2100 & 3078 & 3398 & 2575 & 2060 & 2870 \\
expend. & capita & 2012 & 4545 & 3759 & 3506 & 5738 & 4860 & 3492 & 4675 \\
Current & Pct. of & 2002 & 8.7 & 7.4 & 9.6 & 6.1 & 8.4 & 6.8 & 10.1 \\
expend. & GDP & 2012 & 10.5 & 9.3 & 8.7 & 6.2 & 10.9 & 8.5 & 10.8 \\
Out-of- & US doll/ & 2002 & 405 & 469 & 572 & 572 & 433 & 236 & 358 \\
pocket & capita & 2012 & 586 & 705 & 629 & 849 & 749 & 340 & 663 \\
\hline
\end{tabular}

Note: When interpreting the data on health care expenditure it has to be taken into account that there has been a change over time in the definition of health care expenditures which were reported to the OECD. Thus, in contrast to 2002, most countries included health-related long-term care in 2012 when following the guidelines according to "System of Health Accounts 2011" (OECD, Eurostat and WHO, 2011).

Source: OECD (2017b).

\section{Discussion and conclusion}

Mean health and share of the population with good or very good health is higher in the Nordic countries and the UK, as compared to Germany which may support a tentative hypothesis that centrally initiated public health activities matter. However, life expectancy in Germany is similar to what is found in the other countries with centrally initiated public health activities. An exception is Denmark which introduced policies to counter smoking and excessive alcohol consumption relatively late. Recurrent efforts have succeeded in increasing the Danish life expectancy since the mid-1990s in step with the other Nordic countries, but there is still a gap between Denmark and these countries in life expectancy.

Another spectacular development is overweight which has increased in all Nordic countries during the decade studied with Iceland having the highest percentage of the population with $\mathrm{BMI} \geq 25$. There is, however, no indication of Iceland being an outlier in terms of the four non-medical determinants of health that is reported.

Mean self-assessed health in the Nordic countries as weighted by the TTO weights developed for Sweden by Burström et al. (2014) is relatively close together with few statistically significant differences, and higher than in Germany. We use Swedish weights assuming that respondents in other Nordic countries would assign the same weights to the five response categories of self-assessed health. The levels and their statistical variations are between 0.93 and 0.95 on a scale from 0 to 1 in 2012. Substantially, this may be considered as a state of affairs with good accomplishments, although some improvements are still possible. 
A comparison of percentages reporting good or very good health across the lower and the upper income halves indicates that health inequality increased in Germany and Denmark between 2002 and 2012. However, while the change in Germany was Pareto optimal in the sense that the percentage in both income groups increased, although with a faster increase for the upper income group, the same was not true for Denmark, as the percentage reporting good or very good health dropped in the lower income group, while it increased in the upper group. For the remaining Nordic countries (Finland, Iceland, Norway and Sweden), the percentage reporting good or very good health rose faster in the lower income group than in the upper one, thus indicating a reduction in inequality. For the UK, the changes in percentage for the upper and lower income groups were similar, thus indicating unchanged inequality.

We found very low concentration indices in all countries, although they are statistically significantly different from zero. These results are not surprising in the light of what has been found in earlier international studies, for example by van Doorslaer et al. (1997). One may assume that inequality in income may be associated with socio-economic inequalities in health. Our results show that income-related inequalities in health in the Nordic countries are similar or lower than in less egalitarian countries like Germany and the UK. The differences across countries as well as tendencies over time in the concentration indices are comparable to those shown for percentages reporting good or very good health across lower and upper income groups.

It has been indicated by former studies (Brekke and Kverndokk, 2012) that the concentration index may be a misleading measure of health inequality, as a reduction in income inequality (in the sense that income is transferred from the rich to the poor) may lead to an increase in the concentration index, given that those with better health are lifted from the lower income percentiles. However, a comparison of the 2012 Gini and concentration indices is not much supportive of this, as the countries with the lower Gini tends to be those with the lower concentration indices also (with a rank correlation between the two series of around 0.5). Anyway, we are aware that this cross sectional relationship may not necessarily imply a causal relationship. For the case of Denmark and Germany, health inequality rose over time, which may support the suggestion, but the increases are in concert with the distribution of percentages discussed above reporting good or very good health across income groups, where it was shown that the percentage rose faster for those in the upper income group than for those in the lower. Also, the unchanged health inequality for the case of the UK is neither supportive of the suggestion.

The Gini coefficient is shown for 2012 only because 2002 data are not comparable. While ESS reports income in 12 percentiles in 2002, income is reported in deciles in 2012. However, most other results, including concentration indices, are based on income ranks, which are less sensitive to the number of percentiles. The Gini coefficients are lower in the Nordic countries than in Germany and the UK.

We used two approaches to analyse socioeconomic differences in health - one comparing health in two different socioeconomic groups (low and high), the other by computing the concentration index. The first approach is a traditional approach (see for example OECD (2016, p. 72-73)), which uses only limited information (average health in two groups). The concentration index approach is based on information about the whole range of socioeconomic groups (or individuals ranked by socioeconomic status), and their self-reported health status is weighted by a scale that expresses preference weights. Thus, the information contained in this method is more comprehensive. There is no contradiction between results from these two approaches, as they are related to different questions. However, it is important to be aware of the different impressions that are provided by the two approaches. 
The analysis of non-medical determinants of health, which have often been seen as indicators of health behaviour, shows great variation among the countries. Along with traditional determinants, such as tobacco, alcohol and fat, the consumption of sugar is included because it has been shown that excessive intake of sugar leads to a risk of overweight. Similar results were found by Asgeirsdottir and Gerdtham (2016), who concluded that in spite of the often perceived homogeneity of the Nordic populations, there are interesting differences that need to be further explored. Due to the cross-sectional nature of the data, the present study does not allow any causal relations between these determinants and health. But it can be concluded from the observed differences that more can be accomplished in terms of reducing these risk factors. Still, a higher level of most risk factors was found in Germany and the UK.

Resources in health care vary substantially among the countries. Some of this reflects variation in income. Norway with the highest GDP has the greatest share of population employed in health care and the highest expenditures measured in US dollars, but the lowest share of GDP. Although OECD uses common definitions, what is included may differ from country to country and within a country in the course of time. We found no significant association between the use of resources and various measures of health.

\section{Acknowledgements}

Mathias Kifmann, Carl Hampus Lyttkens, Thorhildur Ólafsdóttir and Hannu Valtonen contributed with information on public health policies in each of their countries and with editing of the paper.

There are no conflicts of interest.

\section{References}

Ásgeirsdottir, T.L., Gerdtham, U.-G., (2016). Health behaviour in the Nordic countries. Nordic Journal of Health Economics, 4(1): 7-27.

Beveridge, W., (1942). Social Insurance and Allied Services ["The Beveridge report"]. London: British Library.

Bjerregaard, P. (1994). Samfundsmæssige og sociale forhold, middellevetid og dødelighed. Delrapport fra Sundhedsministeriets middellevetidsudvalg. Copenhagen: Sundhedsministeriet.

Brekke, K.A., Kverndokk, S. (2012). Inadequate Bivariate Measures of Health Inequality: The Impact of Income Distribution. Scandinavian Journal of Economics 114(2), 323-333.

Burström, K., Sun, S., Gerdtham, U.-G., Henriksson, M., Johannesson, M., Levin, L.Å. and Zethraeus, N. (2014). Swedish experience-based value sets for EQ-5D health states. Quality of Life Research, 23(2): 431-442.

Busse, R., Blümel, M. (2014). Germany: Health System Review. WHO: Health Systems in Transition, 16(2), 2014. Geneva: European Observatory on Health and Policies.

Christiansen, T., Lauridsen, J. T., Kifmann, M., Lyttkens, C. H., Ólafsdottir, Th., Valtonen, H. (2018). Health Policy, health and inequality in health in the Nordic countries. COHERE Discussion paper 2018:1. University of Southern Denmark. https://www.sdu.dk/da/om_sdu/institutter_centre/ivoe_virksomhedsledelse_og_oekonomi/fors kning/forskningspublikationer/coherediscussionpapers

Cylus, J., Richardson, E., Findley, 1., Longley, M., O’Neill, C. and Steel, D. (2015). United Kingdom: Health System Review. WHO: Health Systems in Transition. Geneva: European Observatory on Health Systems and Politics. 
Dahl, E., Bergsli, H., van der Well, K.A. (2014). Sosial ulighet i helse - en norsk kunnskapsoversigt. Oslo: Oslos Universitet. https://www.google.dk/search?q=Sosial+ulighed+i+helse+ $\%$ E2\%80\%93+en+norsk+kunnskapsoversikt\&spell=1\&sa=X\&ved=0ahUKEwj026bXmcPXA hXJNhoKHUzsCksQBQgjKAA\&biw=1200\&bih $=584$

European Social Survey 2017. http://www.europeansocialsurvey.org/

Kakwani, N., Wagstaff, A. and van Doorslaer, E. (1997). Socioeconomic inequalities in health: Measurement, computation, and statistical inference. Journal of Econometrics, 77: 87-103.

Lahelma, E., Lundberg, O. (2009). Health inequalities in European welfare states. European Journal of Public Health, 19(5): 445-446.

Lyttkens, C. H., Christiansen, T., Häkkinen, U., Kaarboe, O., Sutton, M. and Welander, A. (2016). The core of the Nordic health care system is not empty. Nordic Journal of Health Economics, 4: 7-27.

OECD, Eurostat and WHO (2011). System of Health Accounts 2011. Paris: OECD Publishing.

OECD (2015). OECDStat. Health Status. Perceived health status by age and gender. Paris: OECD. http://stats.oecd.org/index.aspx ?queryid=30117

OECD/EU (2016). Health at a Glance: Europe 2016: State of Health in the EU Cycle. PARIS: OECD. http://www.keepeek.com/Digital-Asset-Management/oecd/social-issues-migrationhealth/health-at-a-glance-europe-2016_9789264265592-en\#.WPiCdk1Ppow

OECD (2017a). Inequalities in health. Paris: OECD. http://www.oecd.org/health/inequalities-inhealth.htm

OECD (2017b). OECD.Stat. Paris: OECD.

http://stats.oecd.org/Index.aspx ?DataSetCode=HEALTH_STAT

Olsen, K.R., Anell, A., Häkkinen, U., Iversen, T., Ólafsdóttir, T. and Sutton, M .(2016). General practice in the Nordic countries. Nordic Journal of Health Economics, 4(1): 56-67.

https://www.journals.uio.no/index.php/NJHE/article/view/2801

van Doorslaer, E., Koolman, X. (2004). Explaining the differences in income-related health inequalities across European countries. Health Economics, 13: 609-628.

van Doorslaer, E., Wagstaff, A., Bleichrodt, H. et al. (1997). Income-related inequalities in health: Some international comparisons. Journal of Health Economics, 16, 93-112.

WHO (2017). World Health Organization's homepage. Geneva: WHO.

http://www.euro.who.int/en/health-topics/Health-systems/public-health-services

(C) 2018 by the author(s). This article is an open access article distributed under the terms and conditions of the Creative Commons Attribution license (http://creativecommons.org/licenses/by/4.0/). 